\title{
Metallogenic Epoch and Tectonic Setting of Saima Niobium Deposit in Fengcheng, Liaoning Province, NE China
}

\author{
Nan Ju ${ }^{1,2}, *$, Yun-Sheng Ren ${ }^{1}$, Sen Zhang ${ }^{2}$, Zhong-Wei Bi ${ }^{2}$, Lei Shi ${ }^{2}$, Di Zhang ${ }^{2}$, \\ Qing-Qing Shang ${ }^{1}$, Qun Yang ${ }^{1}$, Zhi-Gao Wang ${ }^{1}$, Yu-Chao Gu ${ }^{2}$, Qiu-Shi Sun ${ }^{2}$ and Tong $\mathrm{Wu}^{2}$ \\ 1 College of Earth Sciences, Jilin University, Changchun 130061, China; renys@jlu.edu.cn (Y.-S.R.); \\ shangqq15@163.com (Q.-Q.S.); yangq2009jlu@163.com (Q.Y.); wzg_jldx@163.com (Z.-G.W.) \\ 2 Shenyang Geological Survey, CGS, Shenyang 110034, China; zhangsen556@163.com (S.Z.); \\ bzw_cgs@163.com (Z.-W.B.); shih1101@163.com (L.S.); zhangdi9521@163.comm (D.Z.); \\ guyi1224@126.com (Y.-C.G.); sunqiushi2007@163.com (Q.-S.S.); jesnet1981@163.com (T.W.) \\ * Correspondence: junan_cgs@163.com; Tel.: +86-024-81847053
}

Received: 17 December 2018; Accepted: 24 January 2019; Published: 29 January 2019

\begin{abstract}
The Saima deposit is a newly discovered niobium deposit which is located in the eastern of Liaoning Province, NE China. Its mineralization age and geochemical characteristics are firstly reported in this study. The $\mathrm{Nb}$ orebodies are hosted by the grey-brown to grass-green aegirine nepheline syenite. Detailed petrographical studies show that the syenite consists of orthoclase $(\sim 50 \%)$, nepheline $(\sim 30 \%)$, biotite $(\sim 15 \%)$ and minor arfvedsonite $(\sim 3 \%)$ and aegirine $(\sim 2 \%)$, with weak hydrothermal alteration dominated by silicification. In situ LA-ICP-MS zircon U-Pb dating indicates that the aegirine nepheline syenite was emplaced in the Late Triassic $(229.5 \pm 2.2 \mathrm{Ma})$, which is spatially, temporally and genetically related to $\mathrm{Nb}$ mineralization. These aegirine nepheline syenites have $\mathrm{SiO}_{2}$ contents in the range of 55.86-63.80 wt. \%, low $\mathrm{TiO}_{2}$ contents of $0.36-0.64$ wt. $\%, \mathrm{P}_{2} \mathrm{O}_{5}$ contents of $0.04-0.11 \mathrm{wt} . \%$ and $\mathrm{Al}_{2} \mathrm{O}_{3}$ contents of more than $15 \mathrm{wt}$. \%. They are characterized by relatively high $\left(\mathrm{K}_{2} \mathrm{O}+\mathrm{Na}_{2} \mathrm{O}\right)$ values of $9.72-15.51$ wt. \%, $\mathrm{K}_{2} \mathrm{O} / \mathrm{Na}_{2} \mathrm{O}$ ratios of $2.42-3.64$ wt. \% and Rittmann indexes $\left(\sigma=\left[\omega\left(\mathrm{K}_{2} \mathrm{O}+\mathrm{Na}_{2} \mathrm{O}\right)\right]^{2} /\left[\omega\left(\mathrm{SiO}_{2}-43\right)\right]\right)$ of $6.84-17.10$, belonging to the high-K peralkaline, metaluminous type. These syenites are enriched in large ion lithophile elements (LILEs, e.g., $\mathrm{Cs}, \mathrm{Rb}$ and $\mathrm{Ba}$ ) and light rare earth elements (LREEs) and relatively depleted in high field strength elements (HFSEs, e.g., $\mathrm{Nb}, \mathrm{Zr}$ and $\mathrm{Ti}$ ) and heavy rare earth elements (HREEs), with transitional elements showing an obvious $\mathrm{W}$-shaped distribution pattern. Based on these geochronological and geochemical features, we propose that the ore-forming intrusion associated with the $\mathrm{Nb}$ mineralization was formed under post-collision continental-rift setting, which is consistent with the tectonic regime of post-collision between the North China Craton and Paleo-Asian oceanic plate during the age in Ma for Indosinian (257-205 Ma). Intensive magmatic and metallogenic events resulted from partial melting of lithospheric mantle occurred during the post-collisional rifting, resulting in the development of large-scale $\mathrm{Cu}$-Mo mineralization and rare earth deposits in the eastern part of Liaoning Province.
\end{abstract}

Keywords: syenite; post-collisional; niobium mineralization; Saima deposit; Liaoning Province

\section{Introduction}

China's reserves of rare earth metals account for up to $87 \%$ of the world total, while the reserves of niobium metals are relatively scarce, which only account for $18.19 \%$ of the world [1]. Geological survey in recent years have shown that most of the niobium $(\mathrm{Nb})$ and tantalum $(\mathrm{Ta})$ deposits are distributed in south China, such as Hunan, Guangdong, Shanxi and particularly Jiangxi Province in which host 
the most abundant $\mathrm{Nb}$ and Ta resources. Minor similar deposits have been sporadically discovered in the Panzhihua-Xichang district, northern Xinjiang and Inner Mongolia [2]. In contrast, few $\mathrm{Nb}$ and $\mathrm{Ta}$ deposits had been discovered in NE China, which was attributed to the restricted prospecting and research at present. However, numerous rare earth deposits associated with alkali rocks represented by Ba'erzhe (inner Mongolia province) have been recently discovered in NE China [3] and rare metals such as $\mathrm{Nb}$ and Ta occurred in alkaline intrusive rocks have received extensive attention.

The Saima deposit, an niobium deposit with medium-scale prospecting potentials, is located about $2 \mathrm{~km}$ to the south of Saima town, Fengcheng city, Liaoning province. Nevertheless, systematic studies on the metallogenic of the newly discovered Saima niobium deposit remain inadequate. In this study, we present new in situ LA-ICP-MS zircon U-Pb geochronological data and whole-rock geochemical data for the ore-forming alkaline intrusive rocks to constrain the timing and origin of the niobium mineralization and in particular, to shed light on the tectonic environment of regional deposition by the views of geological characteristics of the Saima deposit. Moreover, this study provides a scientific basis for further mineral prospecting and future prospecting of new rare earth deposits in NE China.

\section{Geological Setting and Ore Deposit Geology}

The Saima deposit is located in the intersection of the Taizihe-Hunjiang fault depression and Yingkou-Kuandian uplift in the Liaodong Massif, northeast of the North China Craton. Stratigraphic units are dominated by the Neoproterozoic, Cambrian-Ordovician, Jurassic and Quaternary alluvium. Massive Late Archean to Mesozoic granitic intrusions are exposed in the region, with particularly intensive magmatism during Late Triassic and Jurassic. Alkaline rocks closely related to the rare earth deposits are distributed along the intersection between the E-W-trending fault and NNE-SSW-trending fault. This alkaline rock belt extends about $40 \mathrm{~km}$ from east to west, with the width of $15 \mathrm{~km}$, covering an area of about $200 \mathrm{~km}^{2}$. These rocks occurred as small stocks and apophysis and intruded into the Pre-Ordovician formations, showing angular unconformity contact with the overlying Jurassic strata. Four alkaline intrusions and abundant alkaline volcanic-subvolcanic rocks constitute the alkaline rock belt, with their alkalis gradually increasing from east to west and rock types changing from syenite-miascite (biotite-nepheline) to aegirine nepheline syenite. Regional faults are dominated by the E-W-trending faults, accompanied by the NE-SW-trending, NW-SE-trending and NNE-SSW-trending faults. The Saima deposit is located in the intersection of EW-trending fault and NE-SW-trending fault (Figure 1a), as these faults acted as the conduits for the migration and enrichment of ore-forming elements and provided favorable conditions for the formation of an alkaline rock type niobium deposit.

The strata in the Saima district consist of the Lower Proterozoic Gaixian Formation and Dashiqiao Formation, the Upper Proterozoic Xihe Group and Cambrian, Ordovician and Jurassic formations. Intense magmatism developed in the Saima district, including the Proterozoic magmatic rocks exposed in the eastern portion of the district and the Mesozoic magmatic rocks exposed in the western part. The Mesozoic magmatic rocks composed of Fengcheng alkaline intrusion as well as Nanda and Beida granitic intrusions, are controlled by the regional EW-trending faults. The ore-forming alkaline rocks occurred as dikes and stocks along the EW-trending structural zone and are characterized by mediumto fine-grained and pegmatitic textures, which had been interpreted to be the intrusive and flooding products of the Indosinian movement. These rocks are dominated by the aegirine nepheline syenite, accompanied by biotite-bearing aegirine nepheline syenite, black aegirine nepheline syenite, black grenadine syenite, miascite and green or grass-green aegirine nepheline syenite. They belong to the higher $\mathrm{K}_{2} \mathrm{O}$, lower $\mathrm{Na}_{2} \mathrm{O}$, alkaline to peralkaline series. The rare earth mineralization mainly occurred in the green, grass-green and grey-brown aegirine nepheline syenite. It develops EW-, NS-, NE-SW- and NW-SE-trending faults in the Saima district, with the NE-SW-trending faults as the ore-controlling faults [4,5] (Figure 1b). Extensive wall-rock alteration including microclinization, nephelinization, Na-zeolitization and carbonatization are well developed in the Saima deposit. Various kinds of primary nepheline syenite have been extensively altered to syenite, forming the main part of 
the Saima alkaline intrusion. The $\mathrm{Nb}$ and Ta mineralization was closely related to the nephelinization and Ca-nephelinization.
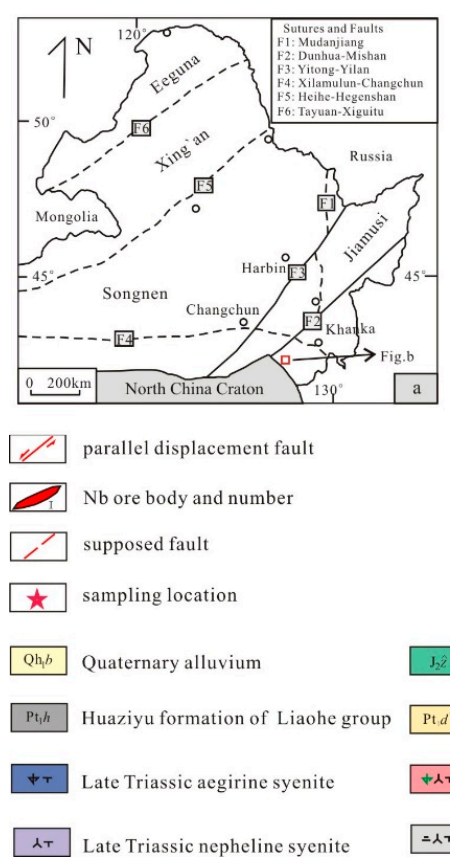

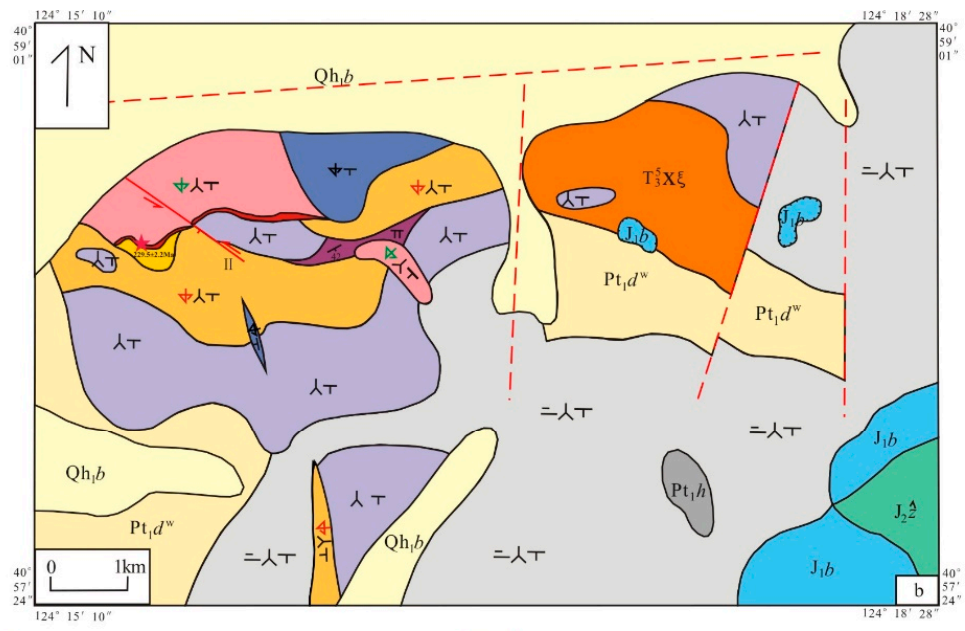

Jurassic Zhuanshanzi formation

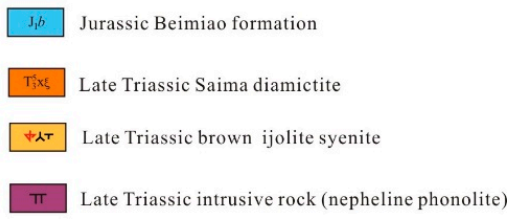

Figure 1. Geotectonic location map (a) and Geological sketch map (b) of Saima deposit in Fengcheng, Liaoning Province (modified from [5]).

Currently, eight orebodies have been found in the Saima district, which mainly occurred in grey-brown to grass-green aegirine nepheline syenite. The No. I and II orebodies are about $500 \mathrm{~m}$ and $160 \mathrm{~m}$ long, with the width of $6 \mathrm{~m}$ and $18 \mathrm{~m}$, respectively. Most of the orebodies are stratiform or lenticular, inclined to $45-115^{\circ}$ and dip at $25-75^{\circ}$, with the maximum thickness up to $40 \mathrm{~m}$ (Figure 2). Fergusonite $\left(\mathrm{YNbO}_{4}\right)$ and brocenite are the dominant ore minerals with high $\mathrm{Nb}$ grades of $0.03-0.06 \%$, Ce grades of about $0.1 \%$. Gangue minerals include nepheline, aegirine, rutile and pyrite. There is no sharp boundary between the orebodies and wall-rocks but rather a gradual transitional relationship. The rare earth ores show lamellated, cataclastic and subhedral pegmatitic textures and veined-disseminated structures.

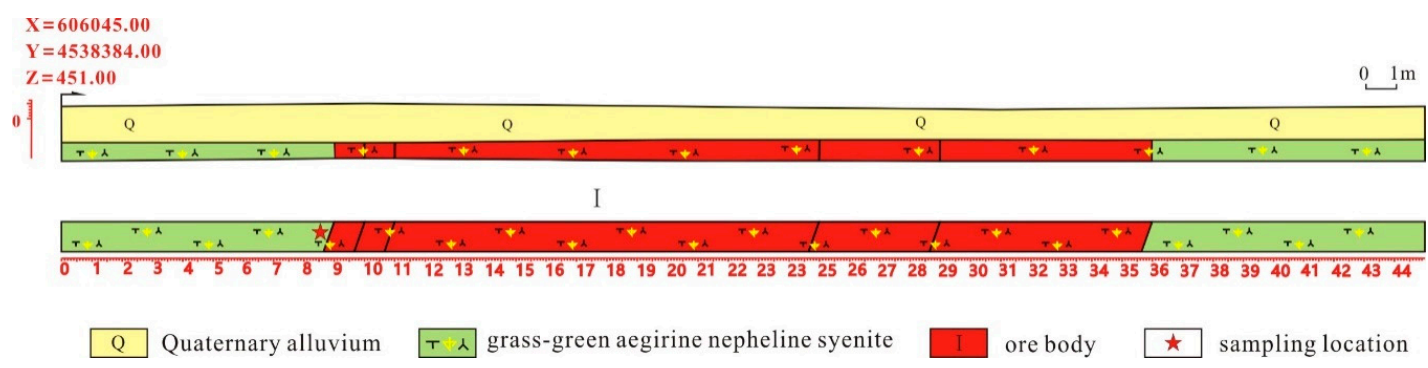

Figure 2. TCG10-3 trench exploration map of the Saima deposit in Fengcheng, Liaoning Province.

\section{Petrography and Analytical Methods}

\subsection{Petrographic Features}

Samples analyzed in this study were collected from the No. II orebody in the Saima district (Figure 1). No (ore) mineralization and alteration had been distinguished in the sample SMB1 and it was considered as the original ore-forming rock. Thin sections were made from these samples and subsequently observed by using an OLYMPUS microscope at the Laboratory of Rock-mineral 
Determination, Jilin University. Detailed petrographic studies indicate that the ore-forming rocks are mainly medium-coarse grained aegirine nepheline syenite composed of subhedral-anhedral orthoclase ( $\sim 50 \%$ ) with carlsbad twinning, nepheline ( $\sim 30 \%)$ with tabular or granular textures, biotite $(\sim 10 \%)$ partly replaced by nepheline, aegirine $(\sim 7 \%)$ and arfvedsonite $(\sim 3 \%$; Figure 3$)$. The aegirine nepheline syenites are in conformable and direct contact with the orebodies as shown in sketch map of TCG10-3 exploratory trench (Figure 2). Combined with the distribution characteristics of orebodies in the deposit scale (Figure 1), it is suggested that the aegirine nepheline syenite is spatially, temporally and genetically related to $\mathrm{Nb}$ mineralization.
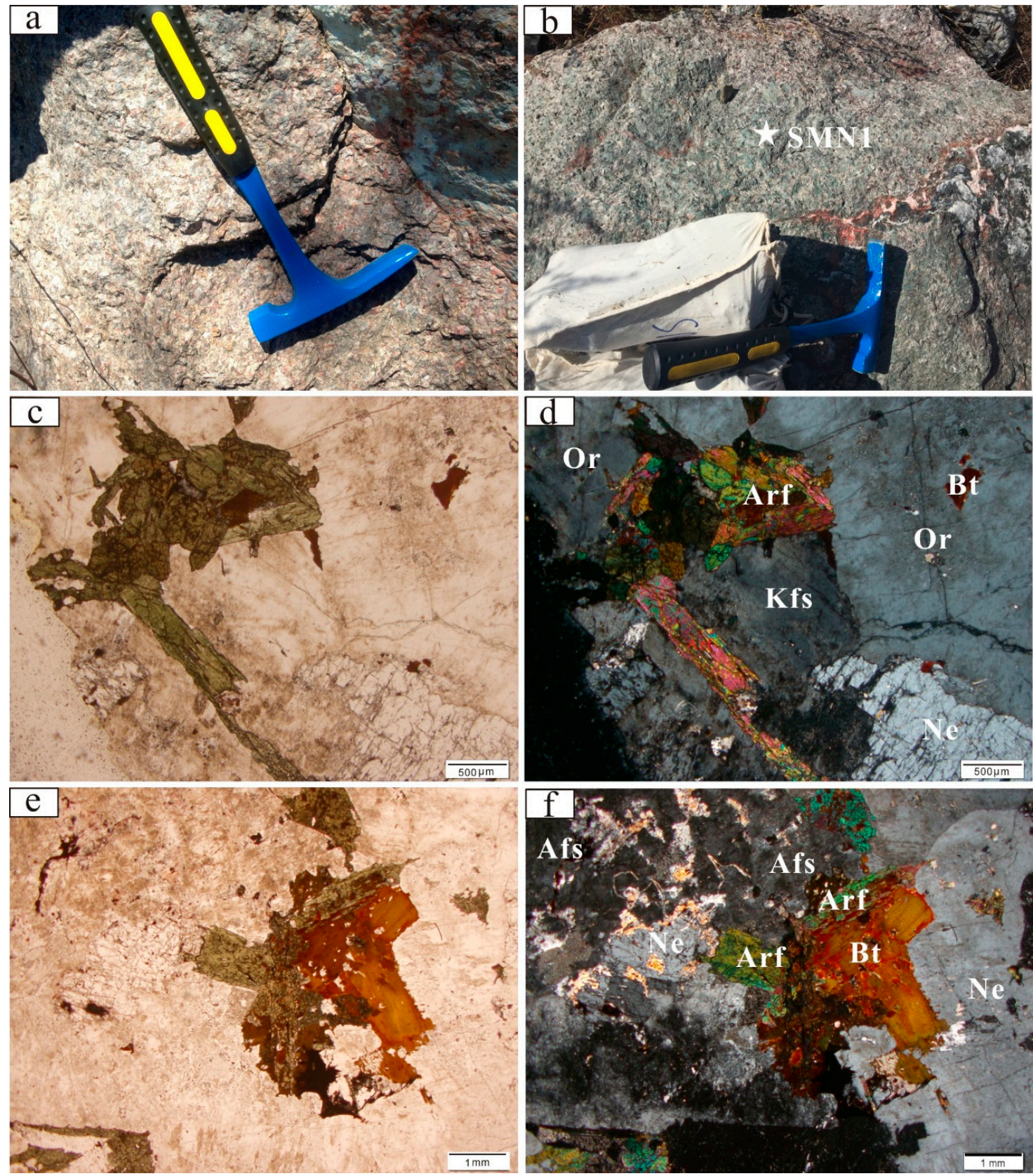

Figure 3. Representative outcrop-pictures and photomicrographs of the ore-forming rocks in Saima niobium deposit. (a) Brown aegirine nepheline syenite; (b) Grass-green aegirine-nepheline syenite(SMN1 is the sample number.); (c) Medium-coarse grained nepheline syenite (PPL); (d) Medium-coarse grained nepheline syenite (CPL); (e) Medium-coarse grained aegirine nepheline syenite (PPL); (f) Medium-coarse grained aegirine nepheline syenite (CPL). Mineral abbreviations: Afs, alkalifeldspar; Arf, arfvedsonite; Bt, biotite; Kfs, K-feldspar; Ne, nepheline; Or, orthoclase. 


\subsection{Analytical Methods}

\subsubsection{Zircon LA-ICP-MS U-Pb Dating}

Sample SMN1 collected from the aegirine nepheline syenite in the Saima district was selected for zircon $\mathrm{U}-\mathrm{Pb}$ dating. Zircons were extracted using conventional heavy liquid and magnetic separation techniques and then handpicked under a binocular microscope at the Langfang Regional Geological Survey, Hebei Province, China. Their transmitted and reflected light images were obtained using a standard polarizing microscope and cathodoluminescence (CL) images were obtained using a JEOL scanning electron microscope (JEOL, Tokyo, Japan). LA-ICP-MS zircon U-Pb analyses were performed using an Agilent 7900 ICP-MS equipped with a 193 nm laser, housed at the Key Laboratory of Mineral Resources Evaluation in Northeast Asia, Ministry of Land and Resources of China, Changchun, China. The zircon 91,500 was used as an external standard for age calibration and the NIST SRM 610 silicate glass was applied for instrument optimization. The beam diameter was $32 \mu \mathrm{m}$ during the analyses. Other instrument parameters and detailed procedures were described by Yuan et al. [6]. Recommended values of $\mathrm{U}-\mathrm{Th}-\mathrm{Pb}$ isotope ratios for zircon standard 91,500 were referred to Wiedenbeck et al. [7] and common $\mathrm{Pb}$ was corrected by applying the methods introduced by Andersen [8]. Weighted averages and intercept ages were calculated using the program Isoplot (Version 4.0, United States Geological Survey, Washington, DC, USA). Errors on individual analyses by LA-ICP-MS are quoted at the $2 \sigma$ level, while errors on the average weighted ages are $2 \sigma$ level.

\subsubsection{Whole-Rock Geochemical Analyses}

Five samples (ore-forming rocks) were selected for major and trace element analyses. After the removal of altered surfaces, fresh whole-rock samples were crushed to 200 meshes in an agate mill. Major oxides were determined by using an inductively coupled plasma-optical emission spectroscopy (ICP-OES) system with high-dispersion echelle optics at the China University of Geosciences, Beijing. Loss on ignition was determined by placing $100 \mathrm{mg}$ of sample in a furnace at $980^{\circ} \mathrm{C}$ for several hours, cooling the sample in a desiccator and then reweighing the sample. Trace element analyses were performed using an Agilent-7500a inductively coupled plasma-mass spectrometer (ICP-MS) at the China University of Geosciences, Beijing. The rock reference materials AGV-2 (USGS) and GSR-3 (National Geological Standard Reference Materials of China) were used to monitor analytic accuracy and precision. Precision and accuracy are better than $5 \%$ for major elements and $10 \%$ for trace elements shown from repeated analyses.

\section{Analytical Results}

\subsection{Zircon $U-P b$ Geochronology}

Most of the zircons from the aegirine nepheline syenite (SMN1) are transparent, euhedral and colorless, with length/width ratios of more than 2:1. Typical oscillatory zoning of magmatic crystallization is common in most of the zircon grains under CL (Figure 4). In addition to their relatively high Th/U ratios (0.5-1.0), a magmatic origin is indicated $[9,10]$. Thirteen zircon $\mathrm{U}-\mathrm{Pb}$ analyses are summarized in Table 1 and have yielded concordant ${ }^{206} \mathrm{~Pb} /{ }^{238} \mathrm{U}$ ages of 233 to $222 \mathrm{Ma}$, with a weighted mean ${ }^{206} \mathrm{~Pb} /{ }^{238} \mathrm{U}$ age of $229.5 \pm 2.2 \mathrm{Ma}(\mathrm{MSWD}=0.54$; Figure 4). 

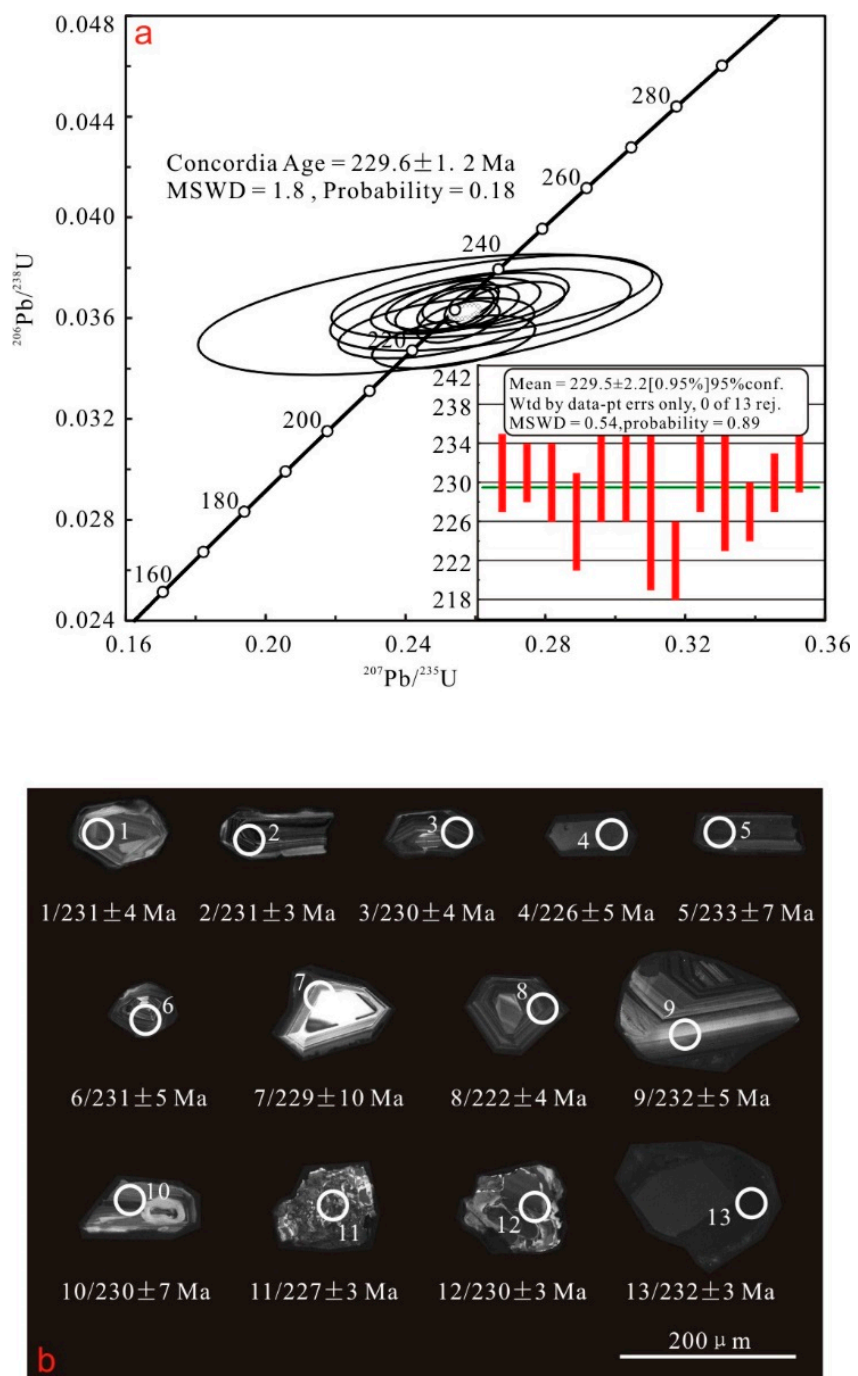

Figure 4. LA-ICP-MS zircon U-Pb concordia diagrams (a) and CL images (b) for the syenite in the Saima deposit.

\subsection{Major and Trace Element Geochemistry}

The whole-rock major and trace element data from the Saima syenites are presented in Tables 2 and 3. The aegirine nepheline syenites have variable $\mathrm{SiO}_{2}$ contents of 55.86-80.94 wt. \% (concentrating in the range of 55.86-63.80 wt. \%) and contain lower $\mathrm{TiO}_{2}$ of $0.36-0.64 \mathrm{wt}$ \%, $\mathrm{P}_{2} \mathrm{O}_{5}$ of $0.04-0.11 \mathrm{wt}$. \% and $\mathrm{Al}_{2} \mathrm{O}_{3}$ of more than $15 \mathrm{wt}$. \% in most of the samples. They are characterized by relatively high total $\left(\mathrm{K}_{2} \mathrm{O}+\mathrm{Na}_{2} \mathrm{O}\right)$ values of $9.72-15.51$ wt. \%, $\mathrm{K}_{2} \mathrm{O} / \mathrm{Na}_{2} \mathrm{O}$ ratios of $2.42-3.64$ wt. $\%$ and Rittmann indexes $\left(\sigma=\left[\omega\left(\mathrm{K}_{2} \mathrm{O}+\mathrm{Na}_{2} \mathrm{O}\right)\right]^{2} /\left[\omega\left(\mathrm{SiO}_{2}-43\right)\right]\right)$ of $6.84-17.10 \mathrm{wt}$. \%, belonging to the high- $\mathrm{K}$ peralkaline, metaluminous syenitoid. These rock samples plot into fields of syenite or nepheline syenite in the TAS and R1-R2 diagrams (Figure 5a,b), into field of calc-alkaline series in the FMA diagram (Figure 5c) and into field of metaluminous rocks in the $(\mathrm{Fe}+\mathrm{Mg}+\mathrm{Ti})-[\mathrm{Al}-(\mathrm{Na}+\mathrm{K}+2 \mathrm{Ca})]$ and $\mathrm{A} / \mathrm{CNK}-\mathrm{A} / \mathrm{NK}$ diagrams (Figure 5d,e). 
Table 1. LA-ICP-MS zircon $\mathrm{U}-\mathrm{Pb}$ analysis results for the syenite in the Saima deposit.

\begin{tabular}{|c|c|c|c|c|c|c|c|c|c|c|c|c|c|c|c|}
\hline \multirow{2}{*}{ Sample No. } & \multicolumn{9}{|c|}{ Isotopic Ratios } & \multicolumn{6}{|c|}{ Age (Ma) } \\
\hline & ${ }^{206} \mathrm{~Pb} /{ }^{238} \mathrm{U}$ & $1 \sigma$ & ${ }^{207} \mathrm{~Pb} /{ }^{235} \mathrm{U}$ & $1 \sigma$ & ${ }^{207} \mathrm{~Pb} /{ }^{206} \mathrm{~Pb}$ & $1 \sigma$ & ${ }^{208} \mathrm{~Pb} /{ }^{232} \mathrm{Th}$ & $1 \sigma$ & ${ }^{232} \mathrm{Th} /{ }^{238} \mathrm{U}$ & ${ }^{206} \mathrm{~Pb} /{ }^{238} \mathrm{U}$ & $1 \sigma$ & ${ }^{207} \mathrm{~Pb} /{ }^{235} \mathrm{U}$ & $1 \sigma$ & ${ }^{208} \mathrm{~Pb} /{ }^{232} \mathrm{Th}$ & 10 \\
\hline 1 & 0.0365 & 0.0006 & 0.2695 & 0.0106 & 0.0535 & 0.0023 & 0.0118 & 0.0002 & 0.8691 & 231 & 4 & 242 & 8 & 238 & 5 \\
\hline 2 & 0.0364 & 0.0005 & 0.2589 & 0.0051 & 0.0515 & 0.0013 & 0.0122 & 0.0002 & 0.3079 & 231 & 3 & 234 & 4 & 246 & 3 \\
\hline 3 & 0.0364 & 0.0006 & 0.2548 & 0.0117 & 0.0508 & 0.0025 & 0.0114 & 0.0002 & 0.8899 & 230 & 4 & 230 & 9 & 229 & 5 \\
\hline 4 & 0.0356 & 0.0008 & 0.2489 & 0.0185 & 0.0507 & 0.0039 & 0.0131 & 0.0003 & 1.2228 & 226 & 5 & 226 & 15 & 263 & 5 \\
\hline 5 & 0.0369 & 0.0011 & 0.2648 & 0.0303 & 0.0521 & 0.0061 & 0.0108 & 0.0004 & 0.9987 & 233 & 7 & 239 & 24 & 218 & 9 \\
\hline 6 & 0.0365 & 0.0007 & 0.2544 & 0.0160 & 0.0506 & 0.0033 & 0.0112 & 0.0004 & 0.7179 & 231 & 5 & 230 & 13 & 226 & 9 \\
\hline 7 & 0.0361 & 0.0016 & 0.2470 & 0.0438 & 0.0496 & 0.0090 & 0.0130 & 0.0012 & 0.5357 & 229 & 10 & 224 & 36 & 262 & 23 \\
\hline 8 & 0.0351 & 0.0007 & 0.2538 & 0.0154 & 0.0525 & 0.0033 & 0.0109 & 0.0004 & 0.5554 & 222 & 4 & 230 & 12 & 219 & 7 \\
\hline 9 & 0.0367 & 0.0008 & 0.2606 & 0.0173 & 0.0516 & 0.0036 & 0.0116 & 0.0003 & 1.7506 & 232 & 5 & 235 & 14 & 232 & 5 \\
\hline 10 & 0.0363 & 0.0011 & 0.2615 & 0.0284 & 0.0522 & 0.0059 & 0.0097 & 0.0005 & 0.6265 & 230 & 7 & 236 & 23 & 195 & 10 \\
\hline 11 & 0.0359 & 0.0006 & 0.2551 & 0.0078 & 0.0516 & 0.0018 & 0.0112 & 0.0002 & 1.1001 & 227 & 3 & 231 & 6 & 226 & 3 \\
\hline 12 & 0.0364 & 0.0005 & 0.2543 & 0.0072 & 0.0507 & 0.0016 & 0.0115 & 0.0001 & 1.5393 & 230 & 3 & 230 & 6 & 232 & 3 \\
\hline 13 & 0.0366 & 0.0006 & 0.2558 & 0.0072 & 0.0506 & 0.0016 & 0.0124 & 0.0001 & 4.8276 & 232 & 3 & 231 & 6 & 249 & 2 \\
\hline
\end{tabular}

Table 2. Whole-rock major oxides (wt. \%) of syenites in the Saima deposit.

\begin{tabular}{ccccccccccccc}
\hline Sample No. & $\mathbf{S i O}_{2}$ & $\mathrm{Al}_{2} \mathbf{O}_{3}$ & $\mathrm{TFe}_{2} \mathbf{O}_{3}$ & $\mathbf{M g O}$ & $\mathbf{C a O}$ & $\mathbf{N a}_{\mathbf{2}} \mathbf{O}$ & $\mathbf{K}_{\mathbf{2}} \mathbf{O}$ & $\mathbf{M n O}$ & $\mathbf{T i O}_{2}$ & $\mathbf{P}_{2} \mathbf{O}_{5}$ & LOI & Total \\
\hline SMH1-1 & 63.80 & 15.25 & 3.50 & 0.51 & 1.59 & 2.57 & 9.36 & 0.09 & 0.36 & 0.10 & 2.89 & 100.02 \\
SMH1-2 & 80.94 & 1.16 & 2.64 & 0.03 & 1.26 & 2.53 & 7.18 & 0.07 & 0.46 & 0.04 & 3.69 & 100.00 \\
SMH1-3 & 57.16 & 19.11 & 3.72 & 0.45 & 1.57 & 4.53 & 10.98 & 0.08 & 0.41 & 0.08 & 1.90 & 99.99 \\
SMH1-4 & 57.38 & 18.11 & 3.68 & 0.53 & 1.95 & 4.07 & 10.25 & 0.09 & 0.64 & 0.11 & 3.18 & 99.98 \\
SMH1-5 & 55.86 & 18.81 & 3.96 & 0.70 & 2.11 & 4.25 & 10.58 & 0.10 & 0.62 & 0.11 & 2.91 & 100.00 \\
\hline
\end{tabular}

Table 3. Whole-rock trace and rare-earth elements (ppm) of syenites in the Saima deposit.

\begin{tabular}{|c|c|c|c|c|c|c|c|c|c|c|c|c|c|c|c|c|c|c|c|}
\hline Sample No. & $\mathrm{Li}$ & $\mathrm{Ti}$ & Sc & V & $\mathrm{Cr}$ & Co & $\mathbf{N i}$ & $\mathrm{Cu}$ & Zn & Ga & $\mathbf{R b}$ & $\mathrm{Sr}$ & $\mathrm{Y}$ & Mn & $\mathrm{Zr}$ & $\mathrm{Nb}$ & $\mathrm{Hf}$ & Cs & Ba \\
\hline SMH1-1 & 69.94 & 2608.20 & 2.30 & 64.87 & 15.26 & 7.07 & 0.92 & 30.94 & 85.41 & 29.11 & 312.20 & 2846.00 & 73.54 & 804.80 & 410.80 & 37.89 & 9.06 & 2.90 & 3366.00 \\
\hline SMH1-2 & 61.38 & 4044.60 & 1.40 & 71.03 & 12.84 & 4.79 & 0.12 & 28.83 & 73.26 & 24.17 & 214.20 & 1171.20 & 77.84 & 706.20 & 888.20 & 106.59 & 20.30 & 2.93 & 2528.00 \\
\hline SMH1-3 & 40.37 & 2552.40 & 1.88 & 61.56 & 14.45 & 4.46 & 0.91 & 25.42 & 98.48 & 30.28 & 290.20 & 2750.00 & 49.60 & 676.40 & 380.40 & 34.79 & 7.84 & 2.50 & 2708.00 \\
\hline SMH1-4 & 55.55 & 4221.00 & 2.45 & 60.91 & 15.32 & 5.14 & 2.45 & 29.01 & 98.51 & 30.49 & 287.60 & 2900.00 & 112.72 & 766.80 & 629.80 & 69.39 & 14.05 & 2.95 & 2912.00 \\
\hline SMH1-5 & 51.15 & 3943.80 & 2.47 & 59.11 & 13.10 & 5.953 & 0.51 & 26.30 & 103.14 & 32.06 & 292.80 & 2742.00 & 154.16 & 774.80 & 532.60 & 74.74 & 11.89 & 2.93 & 2396.00 \\
\hline Sample No. & $\mathrm{La}$ & $\mathrm{Ce}$ & $\operatorname{Pr}$ & $\mathrm{Nd}$ & Sm & Eu & Gd & $\mathrm{Tb}$ & Dy & Ho & Er & $\mathrm{Tm}$ & $\mathrm{Yb}$ & $\mathrm{Lu}$ & $\mathrm{Ta}$ & $\mathrm{Pb}$ & Th & $\mathrm{U}$ & \\
\hline SMH1-1 & 227.60 & 446.00 & 48.36 & 159.80 & 26.62 & 7.38 & 19.04 & 2.56 & 13.27 & 2.48 & 6.65 & 0.83 & 4.85 & 0.56 & 1.41 & 60.88 & 127.10 & 18.02 & \\
\hline SMH1-2 & 91.50 & 186.02 & 26.80 & 95.36 & 19.87 & 6.02 & 15.95 & 2.73 & 16.60 & 3.41 & 9.95 & 1.37 & 8.16 & 0.94 & 2.66 & 48.80 & 124.42 & 38.53 & \\
\hline SMH1-3 & 176.90 & 320.60 & 33.80 & 110.90 & 19.39 & 5.53 & 14.37 & 1.95 & 9.95 & 1.80 & 4.61 & 0.55 & 3.01 & 0.34 & 1.42 & 69.53 & 89.85 & 13.03 & \\
\hline SMH1-4 & 340.00 & 667.60 & 77.48 & 233.40 & 38.34 & 10.59 & 27.82 & 3.81 & 19.91 & 3.70 & 9.78 & 1.22 & 6.98 & 0.81 & 2.60 & 79.18 & 189.32 & 32.25 & \\
\hline SMH1-5 & 466.00 & 946.00 & 108.26 & 331.60 & 55.38 & 15.14 & 40.24 & 5.56 & 29.08 & 5.35 & 13.87 & 1.67 & 9.08 & 0.99 & 2.35 & 56.45 & 275.50 & 41.75 & \\
\hline
\end{tabular}



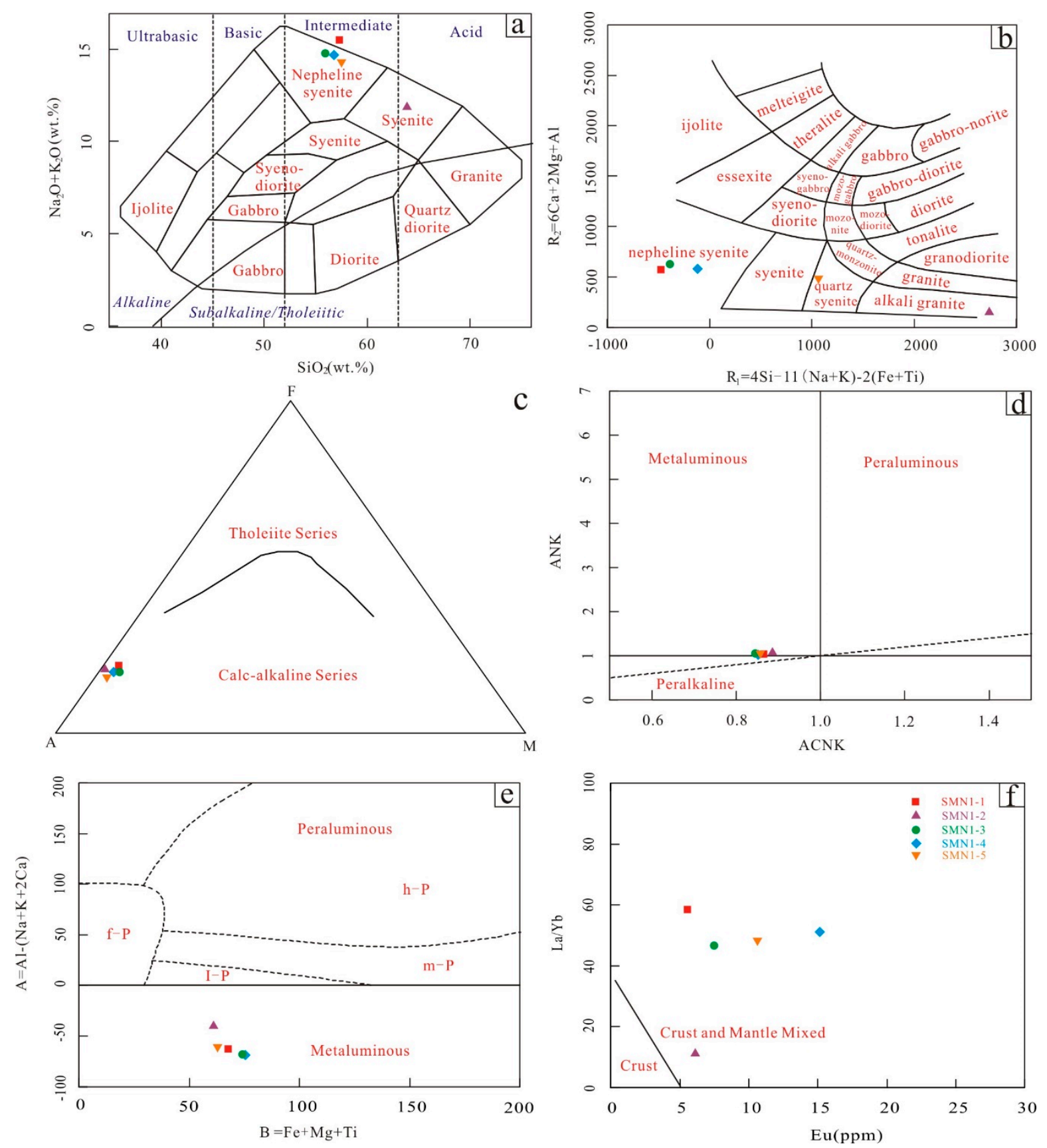

Figure 5. Geochemical classification diagrams for the syenites in the Saima deposit. (a) TAS diagram. (b) R2 vs. R1 diagram. (c) FAM diagram. (d) A/NK vs. A/CNK diagram. (e) [Al - (Na + K + 2Ca)] vs. (Fe + Mg + Ti) diagram. (f) La/Yb vs. Eu diagram (after Le Maître 1989; after Middlemost, 1994; after Irvine, 1971) [11-13].

In the primary mantle (PM)-normalized trace element diagram (Figure 6a), the aegirine nepheline syenites are enriched in LILEs (e.g., $\mathrm{Cs}$, $\mathrm{Rb}$ and $\mathrm{Ba}$ ) and depleted in HFSEs (e.g., $\mathrm{Nb}, \mathrm{Zr}$, Ti), suggesting that the origin of associated parent magmas is related to the enriched mantle. In addition, these samples have relatively high $\mathrm{Nb}$ contents of $34.79-106.59 \mathrm{ppm}$ and are potentially able to provide ore-forming materials for the $\mathrm{Nb}$ mineralization. Moreover, the transitional elements show an obvious W-shaped distribution pattern, which are consistent with those from the mantle-derived granite and mafic intrusions formed under continental-rift setting [14].

The aegirine nepheline syenites have variable REE contents varying from 0.34 to $946.00 \mathrm{ppm}$, with high LREE/HREE ratios of 7.20-18.48 (Table 3). In the chondrite-normalized REE diagram (Figure 6b), 
these syenites are enriched in LREEs and depleted in HREEs, with high $(\mathrm{La} / \mathrm{Yb})_{\mathrm{N}}$ ratios of 7.56-39.58, $\mathrm{Nb} / \mathrm{Ta}$ ratios of 24.56-40.04 and low $(\mathrm{Rb} / \mathrm{La})_{\mathrm{N}}$ ratios of $0.31-1.14$. All of the samples have insignificant negative $\mathrm{Sr}$ and $\mathrm{Eu}$ anomalies $\left(\mathrm{Eu} / \mathrm{Eu}^{*}=0.94-1.00\right)$. Considering that the depletions of $\mathrm{Sr}$ and Eu were caused by the crystallization of plagioclase or residue in the source [5,15-18], it is suggested that the plagioclase is absent in the magmatic source of aegirine nepheline syenites. Additionally, the relatively enriched LREEs indicate the presence of garnet as residual mineral in the source [19-24].
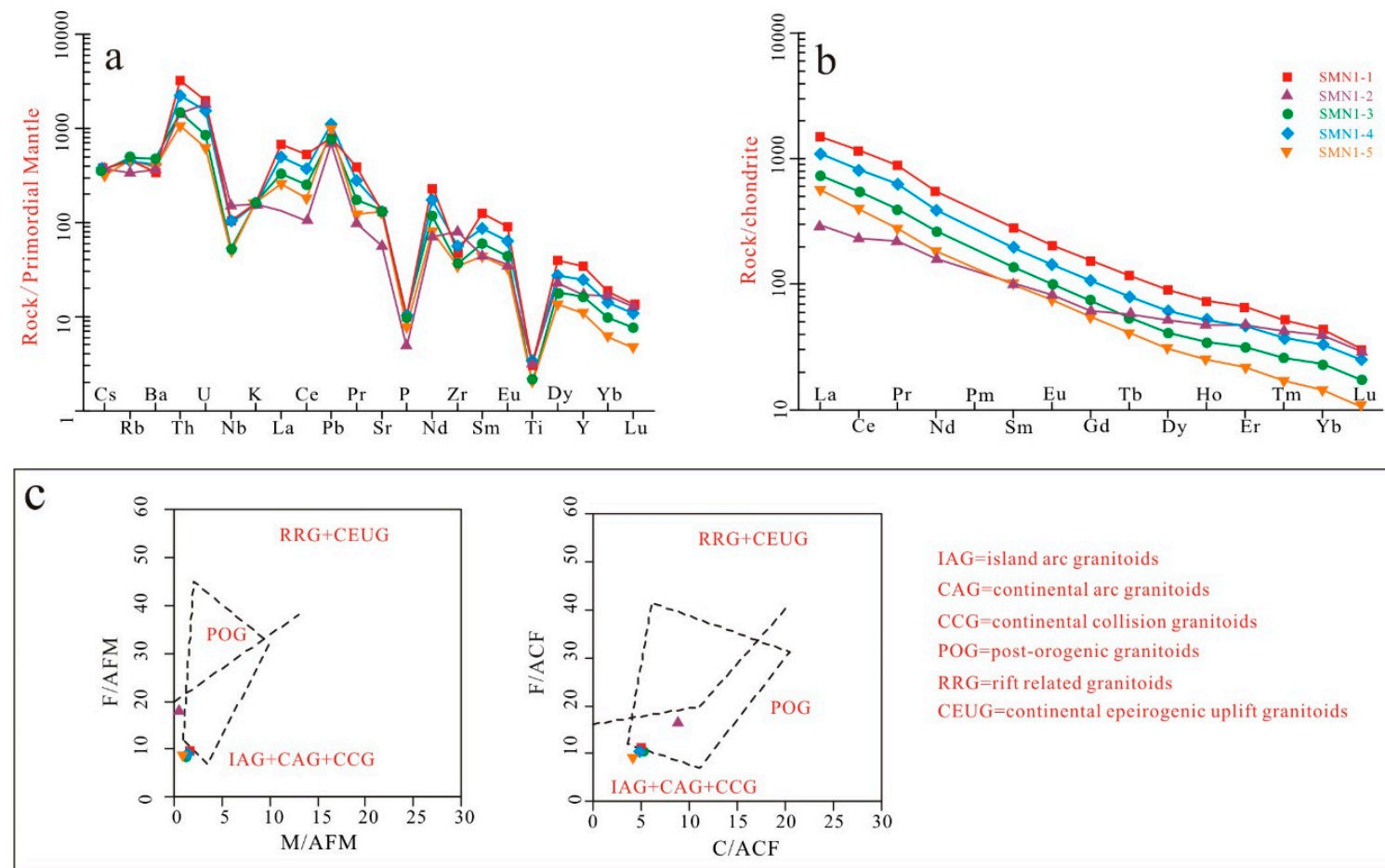

$\mathrm{IAG}=$ island arc granitoids $\mathrm{CAG}=$ continental arc granitoids $\mathrm{CCG}=$ continental collision granitoids $\mathrm{POG}=$ post-orogenic granitoids $R R G=$ rift related granitoids $\mathrm{CEUG}=$ continental epeirogenic uplift granitoids
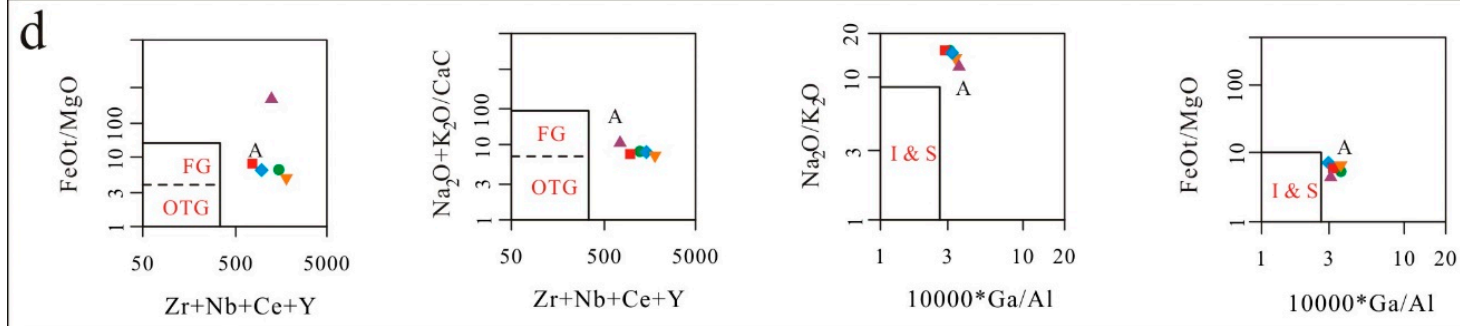

Figure 6. Geochemical classification diagrams for the syenites in the Saima deposit. (a) Primitive mantle-normalized trace-element diagram (normalized data from Sun and Mcdonough,1989); (b) Chondrite-normalized rare-earth element (REE) patterns (normalized data from Boynton, 1984); (c,d) Structural discriminant diagram (after Defant and Drummond, 1990; modified from Pearce 1982) [25-28].

\section{Discussion}

\subsection{Timing of $\mathrm{Nb}$ Mineralization}

Based on the Mesozoic diagenetic and metallogenic ages obtained from previous studies in the NE China, three large-scale mineralization events have been identified [29-33]. Chen and Liu et al. pointed out that the Jia-Meng Continental Block collided with the North China Craton along the Xra Moron-Changchun-Yanji Suture Zone, resulted in the intracontinental crustal shortening and thickening and the formation of crustal-derived granitoids and related $\mathrm{Cu}-\mathrm{Mo}-\mathrm{REE}$ mineralization during 255-190 Ma. During 200-130 Ma, a series of EW-, NE-trending regional faults and their secondary faults were developed and reactivated due to the subduction of the Palaeo-Pacific Plate 
beneath the Eurasian Continent. These faults have provided channels for the ascent of magmas and ore-forming materials, leading to the most intensive mineralization in NE China. North China and Siberian plates collided during 150-120 Ma, resulting in the crustal thickening and the generation of intermediate to felsic magmas and ore-forming fluids. At the same time, the subduction of Pacific oceanic plate entered the peak period at about $140 \mathrm{Ma}$. The regional tectonic framework in eastern China was then evolved into the coastal western Pacific tectonic domain, leading to the development of the coastal Pacific metallogenic system. These above three large-scale magmatic-mineralized events occurred in NE China, corresponding to the initial subduction and subduction peak of the Palaeo-Pacific Plate, as well as the closure of the Paleo-Asian Ocean Plate, respectively. This reflects that the Mesozoic mineralization events in NE China are associated with the conjunction of multiple plates.

In terms of the Late Triassic intrusive rocks in the eastern Liaoning Province, they were formed under an intracontinental orogenic setting with thickened continental crust. During the earliest Late Triassic, the Liaodong Peninsula was in the retention stage of uplifted mantle, causing the emplacement of massive ultramafic-mafic complex and diorite-quartz diorite-tonalite association along the large-scale lateral ductile shear zone. With the development of intracontinental orogenesis, abundant calc-alkaline granitic rocks originated from the remelting of thickened continental crust emplaced in the Liaodong Peninsula. While, post-orogenic collapse occurred after intracontinental orogeny in the latest Triassic [34-36], crustal thinning and the upwelling of mantle-derived magmas resulted in the formation of A-type granites and alkaline complex represented by Saima syenites, which marked the end of the Indosinian magmatism and orogenic cycle.

Sixteen zircon grains with typical magmatic origin from Saima syenite have yielded a weighted mean ${ }^{206} \mathrm{~Pb} /{ }^{238} \mathrm{U}$ age of $229.5 \pm 2.2 \mathrm{Ma}$ (Figure 4), indicating that the ore-related aegirine nepheline syenite emplaced in the Late Triassic. In other words, the metallogenic age of Saima $\mathrm{Nb}$ deposit is the Late Triassic. The $\mathrm{Nb}$ mineralization at Saima was the product of latest Triassic large-scale mineralization in NE China [31].

\subsection{Implications for Tectonic Setting}

Recently, it is widely acknowledged that the distribution of REE deposits and their ore-forming rocks were controlled by regional faults in the margins of plates and tectonic conjunctions. This type of REE deposit was genetically related to the magmatism, which shows that the distribution of $\mathrm{Nb}$ and Ta metallogenic belt was spatially consistent with the occurrence of magmatic rocks in Liaoning Province [1,37-39]. With the deepening of the research on the alkaline rocks, a series of accurate data have been acquired, indicating that the alkali-rich igneous rocks are generally derived from the deep source. These alkaline rocks involve the messages of deep geodynamic processes in the shallow crust, which could reflect the compositions and geodynamic settings of deep earth, the superstructure of the crust and physico-chemical conditions, as well as the concentrations of rare metals in melts. Alkalic complex was known as the product of stable continental rift magmatism and deep fault movements and this property could bring important information about the composition, evolution, tectonic setting and physico-chemistry of deep earth $[40,41]$.

Previous studies have shown that the abnormal geochemical behaviors of $\mathrm{Nb}$ and $\mathrm{Ta}$ and the ranges of $\mathrm{Nb} / \mathrm{Ta}$ values during magmatic-hydrothermal processes can reflect the genesis and origin of magmas. The $\mathrm{Nb} /$ Ta values from the $\mathrm{C} 1$ type chondrite, primitive mantle (PM), depleted mantle (DM) and continental crust are 17.3-17.6, 17.5, 15.5 and 10-14, respectively. Igneous rocks distributed along the deep fault or rift zone show strong enrichments of $\mathrm{Nb}$ and $\mathrm{Ta}$, with remarkable high $\mathrm{Nb} / \mathrm{Ta}$ values than those of primitive mantle [42-46]. The ore-forming syenites in the Saima deposit have obviously higher $\mathrm{Nb}$ / Ta values of 24.56-40.04 than those of primitive mantle, which further demonstrated that the Saima syenites were derived from the deep mantle in an extensional environment. Moreover, the syenite samples plot in the field of crust-mantle mixed source in the La/Yb-Eu diagram (Figure 5f). In addition, the Saima syenites show enrichments in $\mathrm{Sr}$ and $\mathrm{Nd}$ and depletion in Hf, revealing that the asthenospheric mantle had contributed to the generation of ore-related alkaline magmas with 
$\mathrm{Nb}$ and $\mathrm{Ta}$ enrichments and high $\mathrm{Nb} / \mathrm{Ta}$ values. All of the rock samples obtained from the Saima deposit plot in the fields of within-plate, post-collision and rift- granitoids in the tectonic environment discriminant diagrams (Figure $6 c, d$ ). The above geochemical characteristics are consistent with those of ore-forming rocks from the same type of deposits and we thus infer that the aegirine nepheline syenite is the ore-forming rock of Saima $\mathrm{Nb}$ deposit formed under post-collisional rift setting. The basic characteristics of the deposit are basically consistent with those of typical alkaline-type rare earth deposits, for example, Strange Lake $\mathrm{Nb}$ deposit (Canada), Ghurayyah Nb deposit (Saudi Arabia), Khaldzan Buregte (Mongolia) and so on [47,48].

As discussed above, the formation of ore-related aegirine nepheline syenite in the Saima $\mathrm{Nb}$ deposit is mainly attributed to crust-mantle mixing. The mineralized processes are summarized as follows. The crust relaxed and thinned after the termination of intracontinental orogeny in the Late Indosinian, causing the upwelling of mantle-derived magmas along the weak zone of a fault system and rising abundant ore-forming materials from deep mantle. The low-degree melting of mantle had resulted in the enrichment of incompatible elements (e.g., LILEs and REEs) and volatile components for the Saima deposit. The aegirine nepheline syenites are enriched in high field-strength elements (particularly for $\mathrm{Nb}, \mathrm{Ta}, \mathrm{Zr}$ and $\mathrm{Hf}$ ) and LREEs that were higher than those of background values of crust [49-52], which provide preferable conditions for the formation of $\mathrm{Nb}$ mineralization.

\section{Conclusions}

(1) The $\mathrm{Nb}$ orebodies mainly occurred in grey-brown to grass-green aegirine nepheline syenite in the Saima deposit, with fergusonite and brocenite as the dominant ore minerals, which are consistent with the typical alkaline-type REE deposit in China.

(2) In situ LA-ICP-MS zircon U-Pb dating indicates that the aegirine nepheline syenite was emplaced in Late Triassic $(229.5 \pm 2.2 \mathrm{Ma})$, which are spatially, temporally and genetically related to $\mathrm{Nb}$ mineralization.

(3) The medium-coarse grained aegirine nepheline syenites are high-K peralkaline, metaluminous syenitoid, with relatively high $\mathrm{Nb} / \mathrm{Ta}$ ratios.

(4) The Saima $\mathrm{Nb}$ deposit was formed under the post-collision continental-rift setting, which is consistent with the tectonic regime of post-collision between the North China Craton and Paleo-Asian oceanic plate during the Indosinian. Intensive magmatic and metallogenic events caused by partial melting of lithospheric mantle occurred under the post-collisional rifting, resulting in the development of large-scale $\mathrm{Cu}-\mathrm{Mo}$ mineralization and rare earth deposits in the eastern of Liaoning Province.

Author Contributions: Conceptualization, Z.-W.B.; Data curation, S.Z., Q.-Q.S., Q.Y. and Z.-G.W.; Methodology, Y.-C.G. and Q.-S.S.; Software, L.S., D.Z. and T.W.; Writing—original draft, Y.-S.R.; Writing—review \& editing, N.J.

Funding: This research was funded by the China Geological Survey Project, grant No. DD20160131.

Acknowledgments: We thank the geologists from the Shenyang Geological Survey of CGS with their assistance in the field work for the Saima $\mathrm{Nb}$ deposit.

Conflicts of Interest: The authors declare no conflict of interest.

\section{References}

1. Chen, G.; Zhao, J.; Zhai, Y. Shaolahazi alkaline rock Nb-Ta mineralization characteristics and prospecting direction of alkaline rocks in the central part of Jilin Province. Jilin Geol. 2011, 30, 36-39. (In Chinese with English abstract).

2. Cai, X.; Song, Y. Distribution of niobium and tantalum minerals and metallogenic conditions in northeast China. Ore Depos. Geol. 2014, 33, 1155-1156. (In Chinese with English abstract).

3. Mao, C.X.; Zheng, C.Q.; Bi, Z.W.; Yang, Y.J.; Cai, L.; Zhang, C.P. Preliminary Study on the Prospectng Potentlal of Niobium-Tantalum Deposite in Daxinganling Region. Geol. Resour. 2016, 25, 269-274. (In Chinese with English abstract). 
4. Sun, L.J.; Zhang, Y.H.; Yu, J.H. Discussion Geological Features and Age on the Alkaline-Complex of Fengcheng of the Eastern Liaoning. J. Liaoning Commun. Coll. 2008, 10, 41-44. (In Chinese with English abstract).

5. Ju, N.; Zhang, S.; Bi, Z.W.; Shi, L.; Zhang, D. Study on ore-forming conditions of fengcheng horse niobium deposit in Liaoning Province. J. Miner. Sci. 2017, supplement, 189. (In Chinese with English abstract).

6. Yuan, H.L.; Gao, S.; Liu, X.M.; Li, H.M.; Gunther, D.; Wu, F.Y. Accurate U-Pb age and trace element determinations of zircon by laser ablation-inductively coupled plasma-mass spectrometry. Geostand. Geoanal. Res. 2004, 28, 353-370. [CrossRef]

7. Wiedenbeck, M.; Alle, P.; Corfu, F.; Griffin, W.L.; Meier, M.; Oberli, F.; Spiegel, W. Three natural zircon standards for U-Th-Pb, Lu-Hf, trace element and REE analyses. Geostand. Geoanal. Res. 1995, 19, 1-23. [CrossRef]

8. Andersen, T. Correction of common lead in U-Pb analyses that do not report $204 \mathrm{~Pb}$. Chem. Geol. 2002, 192, 59-79. [CrossRef]

9. Belousova, E.A.; Griffin, W.L.; O'Reilly, S.Y. Igneous zircon: Trace element composition as an indicator of source rock type. Contrib. Mineral. Petrol. 2002, 143, 602-622. [CrossRef]

10. Hoskin, P.W.O.; Schaltegger, U. The composition of zircon and igneous and metamorphic petrogenesis. Rev. Mineral. Geochem. 2003, 53, 27-62. [CrossRef]

11. Middlemost, E.A.K. Naming materials in the magma/igneous rock system. Earth Sci. Rev. 1994, 37, $215-224$. [CrossRef]

12. Le Maitre, R.W.; Bateman, P.; Dudek, A.; Keller, J.; Lameyre, J.; Le Bas, M.J.; Sabine, P.A.; Schmid, R.; Sorensen, H.; Streckeisen, A.; et al. A Classification of Igneous Rocks and Glossary of Terms; Blackwell: Oxford, UK, 1989.

13. Irvine, T.N.; Baragar, W.R.A. A guide to the chemical classification of the common volcanic rocks. Can. J. Earth Sci. 1971, 8, 523-548. [CrossRef]

14. Niu, H.C.; Shan, Q.; Chen, X.M.; Zhang, H.Y. The relation between light rare earth deposits and slow earth processes in the pangxi rift zone. Sci. China 2002, 32, 33-40. (In Chinese with English abstract).

15. Bakker, R.J.; Elburg, M.A. A magmatic-hydrothermal transition in Arkaroola (northern Flinders Ranges, South Australia): From diopside-titanitepegmatites to hematite-quartz growth. Contrib. Mineral. Petrol. 2006, 152, 541-569. [CrossRef]

16. Qiu, K.F.; Yu, H.C.; Gou, Z.Y.; Liang, Z.L.; Zhang, J.L.; Zhu, R. Nature and origin of Triassic igneous activity in the Western Qinling Orogen: The Wenquan composite pluton example. Int. Geol. Rev. 2018, 60, 242-266. [CrossRef]

17. Bonin, B. Alkaline rocks and geodynamics. Turk. J. Earth Sci. 1998, 7, 105-118.

18. Crockettand, R.N.; Sutphin, D.M. International Strategic Minerals Inventory Summary Report-Niobium and Tantalum; Circular 930-M; U.S. Geological Survey: Reston, VA, USA, 1993; 36p.

19. Cai, J.H.; Yan, G.H.; Xu, B.L.; Wang, G.Y.; Mou, B.L.; Zhao, Y.C. The Late Mesozoic Alkaline Intrusive Rocks at the East Foot of the Taihang-Da Hinggan Mountains: Lithogeochemical Characteristics and Their Implications. J. Earth 2006, 27, 447-459. (In Chinese with English abstract).

20. Deng, J.; Wang, Q.F.; Li, G.J.; Santosh, M. Cenozoic tectono-magmatic and metallogenic processes in the Sanjiang region, southwestern China. Earth-Sci. Rev. 2014, 138, 268-299. [CrossRef]

21. Liu, X.Y.; Cai, J.H.; Yan, G.H. Petrogeochemical characteristics and geological significance of ancient middle proterozoic alkali rocks in the southern margin of north China craton. Ore Depos. Geol. 2010, 29, 1109-1110. (In Chinese with English abstract).

22. Geng, J.Z.; Qiu, K.F.; Gou, Z.Y.; Yu, H.C. Tectonic regime switchover of Triassic Western Qinling Orogen: Constraints from LA-ICP-MS zircon $\mathrm{U}-\mathrm{Pb}$ geochronology and $\mathrm{Lu}-\mathrm{Hf}$ isotope of Dangchuan intrusive complex in Gansu, China. Chem. Erde Geochem. 2017, 77, 637-651. [CrossRef]

23. Wang, F.L.; Zhao, T.P.; Chen, W. Advances in study of Nb-Ta ore deposits in Panxi area and tentative discussion on genesis of these ore deposits. Ore Depos. Geol. 2012, 31, 293-308. (In Chinese with English abstract).

24. Wang, P.X.; Bao, M.W. General Situation and Prospecting Revelation of Tantalum-Niobium Rare Metal Deposits in China. Met. Mines 2015, 468, 92-97. (In Chinese with English abstract). 
25. Sun, S.S.; McDonough, W.F. Chemical and isotopic systematics of oceanic basalts: Implications for mantle composition and processes. In Magmatism in Oceanic Basins; Saunders, A.D., Norry, M.J., Eds.; Geological society London Special Publications: London, UK, 1989; Volume 42, pp. 313-345.

26. Boynton, W.V. Cosmochemistry of the rare earth elements: Meteorite studies. In Rare Earth Element Geochemistry: Development in Geochemistry; Henderson, P., Ed.; Elsevier: Amsterdam, The Netherlands, 1984; pp. 63-107.

27. Defant, M.J.; Drummond, M.S. Derivation of some modern arc magmas by melting young subducted lithosphere. Nature 1990, 347, 662-665. [CrossRef]

28. Pearce, J.A. Trace element characteristics of lavas from destructive plate boundaries. In Andesits. Chochester; Thorpe, R.S., Ed.; Wiley: Hoboken, NJ, USA, 1982; pp. 525-548.

29. Wu, F.Y.; Jahn, B.M.; Wilde, S.; Sun, D.Y. Phanerozoic continental crustal growth: U-Pb and Sr-Nd isotopic evidence from the gran-ites in northeastern China. Tectonophysics 2000, 328, 89-113. [CrossRef]

30. Zhang, C.H.; Kang, Z.; Zhang, G.Y.; Liu, Y.C. Sequential characteristic of regional mineralization and magmatism of NE, China in Mesozoic. Geol. Resour. 2009, 18, 87-99. (In Chinese with English abstract).

31. Chen, Y.J.; Zhang, C.; Li, N.; Yang, Y.F.; Deng, K. Geology of the Mo Deposits in Northeast China. J. Jilin Univ. (Earth Sci. Ed.) 2012, 42, 1223-1268. (In Chinese with English abstract).

32. Zhang, Y. Research on Characteristics of Geology, Geochemistry and Metallogenic Mechanism of the Jurassic Molybdenum Deposits in the Mid-East Area of Jilin. Ph.D. Thesis, Jilin University, Changchun, China, 2013. (In Chinese with English abstract).

33. Cao, Z.Q.; Hou, G.J. The Late Mesozoic Alkaline Intrusive Rocks at the North of the Da Hinggan Mountains: Lithogeochemical Characteristics and Their Implications. Miner. Rock Geochem. Bull. 2009, 28, 209-216. (In Chinese with English abstract).

34. Deng, J.; Wang, Q.F. Gold mineralization in China: Metallogenic provinces, deposit types and tectonic framework. Gondwana Res. 2016, 36, 219-274. [CrossRef]

35. Deng, J.; Wang, C.M.; Bagas, L.; Carranza, E.J.M.; Lu, Y.J. Cretaceous-Cenozoic tectonic history of the Jiaojia Fault and gold mineralization in the Jiaodong Peninsula, China: Constraints from zircon U-Pb, illite K-Ar and apatite fission track thermochronometry. Miner. Depos. 2015, 50, 987-1006.

36. Cheng, X.H.; Xu, J.H.; Zhang, H. The inclusions in quartz veins in the alkaline rock area of berchon in eastern Liaoning Province. Ore Depos. Geol. 2014, 33, 503-504. (In Chinese with English abstract).

37. He, J.L. Ore-forming Geological Conditions and Prospecting Potential for Nb-Ta Mineral Deposits in Panzhihua-Xichang Region, Sichuan. Geol. J. Sichuan 2004, 24, 206-211. (In Chinese with English abstract).

38. Li, S.P.; Zhan, S.Z.; Jin, T.T.; Chen, J.; Ren, H.; Qiu, W. REE Geochemical Characteristics and Provenance Analysis of the Shaliuquan Niobium Tantalum Pegmatite Ore, Qinghai Province. Rare Earths 2016, 37, $39-46$. (In Chinese with English abstract).

39. Yuan, Z.X.; Bai, G. Temporal and Spatial Distribution of Endogenic Rare and Rare Earth Mineral Deposits of China. Ore Depos. Geol. 2001, 20, 347-354. (In Chinese with English abstract).

40. Yang, L.Q.; Deng, J.; Dilek, Y.; Qiu, K.F.; Ji, X.Z.; Li, N.; Taylor, R.D.; Yu, J.Y. Structure, geochronology and petrogenesis of the Late Triassic Puziba granitoid dikes in the Mianlue suture zone, Qinling Orogen, China. Geol. Soc. Am. Bull. 2015, 127, 1831-1854. [CrossRef]

41. Yang, L.Q.; Deng, J.; Qiu, K.F.; Ji, X.Z.; Santosh, M.; Song, K.R.; Song, Y.H.; Geng, J.Z.; Zhang, C.; Hua, B. Magma mixing and crust-mantle interaction in the Triassic monzogranites of Bikou Terrane, central China: Constraints from petrology, geochemistry and zircon $\mathrm{U}-\mathrm{Pb}-\mathrm{Hf}$ isotopic systematics. J. Asian Earth Sci. 2015, 98, 320-341. [CrossRef]

42. Zhang, P.S.; Yang, Z.M.; Tao, K.J.; Song, R.K. Niobian-Tantalian and Rare Earth Mineralogy in China and Their Industrial Utilization. Rare Met. 2005, 29, 206-210. (In Chinese with English abstract).

43. Nan, J.; Yunsheng, R.; Sen, Z.; Linlin, K.; Di, Z.; Yuchao, G.; Qun, Y.; Hui, W.; Lei, S.; Qiushi, S.; et al. The Early Jurassic Chang'anbu porphyry $\mathrm{Cu}-\mathrm{Mo}$ deposit in Northeastern China: Constraints from zircon $\mathrm{U}-\mathrm{Pb}$ geochronology and H-O-S-Pb stable isotopes. Geol. J. 2018, 53, 2437-2448.

44. Ran, Q.C.; Liu, X.Z. Significance of Contrasting Between Fengcheng Alkali Complex and Related Diamond-Bearing Rocks. J. Chang. Inst. Geol. 1993, 23, 279-285. (In Chinese with English abstract).

45. Ren, J.; Lu, S.C. Survey of world niobium resources and their characteristics. Nonferr. Metall. 1997, 5, 1-3. (In Chinese with English abstract). 
46. Qiu, K.F.; Marsh, E.; Yu, H.C.; Pfaff, K.; Gulbransen, C.; Gou, Z.Y.; Li, N. Fluid and metal sources of the Wenquan porphyry molybdenum deposit, Western Qinling, NW China. Ore Geol. Rev. 2017, 86, 459-473. [CrossRef]

47. Zhu, J.C.; Li, R.K.; Li, F.C.; Xiong, X.L.; Zhou, F.Y.; Huang, X.L. Topaz-albite granites and rare-metal mineralization in the Limu District, Guangxi Province, Southeast China. Miner. Desposita 2001, 36, $393-405$. [CrossRef]

48. Kempe, U.; Gotze, J.; Dandar, S.; Habermann, D. Magmatic and metasomatic processes during formation of the $\mathrm{Nb}-\mathrm{Zr}$-REE deposits Khaldzan Buregte and Tsakhir (Mongolian Altai): Indications from a combined CL-SEM study. Mineral. Mag. 1999, 63, 165-177. [CrossRef]

49. Pal, D.C.; Mishra, B.; Bernhardt, H.J. Mineralogy and geochemistry of pegmatite-hosted Sn-Ta-Nb-and Zr-Hf-bearing minerals from the southeastern part of the Bastar-Malkangiri Pegmatite Belt, Central India. Ore Geol. Rev. 2007, 30, 30-55. [CrossRef]

50. Qiu, K.F.; Yang, L.Q. Genetic feature of monazite and its U-Th-Pb dating: Critical considerations on the tectonic evolution of Sanjiang Tethys. Acta Petrol. Sin. 2011, 27, 2721-2732. (In Chinese with English abstract).

51. Sørensen, H. Alkaline Rocks; Wiley: Hoboken, NJ, USA, 1974; 622p.

52. Shand, S.J. The problem of the alkaline rocks. Proc. Geol. Soc. S. Afr. 1922, 25, 19-33.

(c) 2019 by the authors. Licensee MDPI, Basel, Switzerland. This article is an open access article distributed under the terms and conditions of the Creative Commons Attribution (CC BY) license (http:/ / creativecommons.org/licenses/by/4.0/). 